\title{
The influence of environmental factors on the distribution and composition of plant species in Oued Charef dam, northeast of Algeria
}

\author{
NAOUEL MOUALKI ${ }^{1,2}$, NADHRA BOUKROUMA ${ }^{1, \bullet}$ \\ ${ }^{1}$ Department of Biology, Faculty of Sciences and Nature, University Mohamed Cherif Messaadia. Souk-Ahras, 41000, Algeria. \\ email: nboukrouma@yahoo.fr \\ ${ }^{2}$ Laboratory Sciences et Techniques du Vivant, Institute Agro-vétérinaire,Taoura, University Mohamed Cherif Messaadia. Souk-Ahras, 41000 Algeria
}

Manuscript received: 23 November 2020. Revision accepted: 25 December 2020.

\begin{abstract}
Moualki N, Boukrouma N. 2021. The influence of environmental factors on the distribution and composition of plant species in Oued Charef dam, North East of Algeria. Biodiversitas 22: 346-353. Identification of the primary factors that influence the ecological distribution of species groups is important to managers of Oued Charef dam in northern Algeria. This study aimed to identify main ecological species groups, describe the site conditions associated with these species groups, and the relationships between environmental factors and the distribution of ecological species groups using Ward's cluster analysis for classification and principal component analysis (PCA). For this purpose, 50 plots $\left(200 \mathrm{~m}^{2}\right.$ each) were sampled using the Braun- Blanquet method. Soil samples were collected and analyzed to study soil properties. Multivariate analysis methods were used to classify and determine the relationship between species composition and environmental factors and to recognize ecological species groups. The $R$ i386 (version 4.0.3) software was used for data analyzing. Ward's cluster analysis when applied on terrestrial species data gives three groups distinctly distributed on ordination plan. In cluster groups of terrestrial species Group (1) is dominated by Daisies chrysanthemum, Group (2) by Cynodon dactylon L, and Group (3) dominated by Fumana thymifolia. The groups of terrestrial species are readily superimposed on PCA ordination plane. The most important environmental factors associated with terrestrial species composition in Oued Charef dam communities were conductivity (EC), FSA, FSI, clay, salinity, phosphorus $\left(\mathrm{PO}_{4}\right)$, TN (nitrogen), nitrates $\left(\mathrm{NO}_{3}\right)$, and nitrites $\left(\mathrm{NO}_{2}\right)$. While among the edaphic factors only $\mathrm{pH}$ showed a negative correlation to plant species this may due to the anthropogenic disturbances however further studies are needed to explore the rest of parts of the said regions. This study gives important insights on ecological relationships between plant biodiversity and soil chemical in a primary wetland ecosystem in northeast of Algeria.
\end{abstract}

Keywords: Species groups, relationships, multivariate analysis, terrestrial species, edaphic factors

\section{INTRODUCTION}

Wetlands ecosystems are known for having the highest plant communities on the planet (Skeffington et al. 2006; Hebb et al. 2013; Wetser et al. 2015). These plant communities are the key components of this ecosystem function and stability. It is thought that higher plant communities in wetlands are caused by factors such as high temperature, high humidity, and high solar radiation all year round which favor the growth of a large number of species (Givnish 1999). Although the main causal factors of plant communities are related to environmental factors, it is important to understand what is happening at the microhabitat level. Do soil variables have any effects on plant communities in wetlands?

Many studies have examined relationships between plant communities and soil variables (Dekeyser et al. 2003; O'Connell et al. 2012; Williams and Ahn 2015). These works suggested that soil conditions are the main environmental factors affecting wetland plant communities, namely soil nutrients including nitrogen, phosphorus, and organic carbon (Li et al. 2010; Zheng et al. 2013; Jager et al. 2015; Wang et al. 2016). Wetland vegetation can effectively absorb nutrients from the surrounding soil. Kang et al. (2002) found that soil environmental factors have important effects on plant growth and reproduction. In a more specific study, Janssens et al. (1998) looked at the relationship between plant biodiversity and different soil chemical factors in numerous wetlands ecosystems. They found a positive relationship between plant biodiversity and the concentration of extractable phosphorus and nitrogen in soil Janssens et al. (1998). Recently, Dybzinski et al. (2008) investigated the effects of soil variables in plant species diversity in the grassland ecosystem of Minnesota in the United States. They found that the different soil environmental factors determined the wetland vegetation pattern and process (Dybzinski et al. 2008). Much research has been done on the relationships of plant biodiversity with soil variables in different ecosystems, temperate forests, tropical forests, and agroecosystems. On the other hand, there is a lack of research and data available about this correlation in wetland ecosystems. In this study, we gathered baseline data for the relationship between plant biodiversity and soil variables in Oued Charef dam in northeast of Algeria. This paper deals with the vegetation aspect of a wider study that aimed to classify and evaluate the wetland with respect to soil factors as well as plant communities. We tested the hypothesis that there are some relationships between various plant biodiversity measurements and soil chemical factors. 


\section{MATERIALS AND METHODS}

\section{Study area}

The study was conducted in an arid-hot valley, dam Oued Charef $\left(36^{\circ} 5^{\prime} 22.91 " N 7^{\circ} 23^{\prime} 20.78^{\prime \prime E}\right.$, alt. $920 \mathrm{~m}$ a. s. 1., area: 1010 ha), located in souk Ahras Province, northeast of Algeria (Figure 1). The dam height is $960 \mathrm{~m}$, the normal storage water level is $752 \mathrm{~m}$, the water area is about $1287.18 \mathrm{ha}$, and the total reservoir capacity is $229.85 \mathrm{Hm}^{3}$. The annual precipitation varies in the range $158-480 \mathrm{~mm}$ with more than $70 \%$ concentrated in the winter. The mean annual temperature ranges from 11.9 to $-22^{\circ} \mathrm{C}$. Even though the wetland is comprised of aquatic plants, it is surrounded by cereal crops consisted of Chenopodiaceae (Atriplex halimus, Atriplex patula, Salicornia fruticosa, Salsola fruticosa, Suaeda fruticosa), Brassicaceae (Mauricandia arvensis, Matthiola fruticulosa, Diplotaxis éricoïdes, Capsella bursa-pastoris) (Boukrouma 2017).

\section{Data collection}

Vegetation sampling procedures

Initially, to general reorganize of study area and investigate plant vegetation, a field survey was done. Based on the primary study, major plant species and species selected and sampling were done with a systematically randomized method. In each species site, 3-5 transects with a length of $200 \mathrm{~m}$ each including 10 plots of $1 \mathrm{~m}$ were established.

The area of plots in each plant type was determined by the mini-mum surface method using a nested plot technique and area/species curves (Mueller-Dombois and Ellenberg 1974). The 50 homogenous plots were placed systematically to determine plant distribution and diversity. The vegetation of research plots was surveyed according to Braun-Blanquet (1964). Cover estimates were made for all plant species. The source of the nomenclature was: Martincic et al. (1999) for vascular plants, Coreley et al. (1981), Grolle and long (2000) for liverworts. According to the phytosociological units, the source of characterization of the plant species was Oberdorfer $(1983,1992)$. From all the 50 research plots we took soil samples at depths of 0-20 $\mathrm{cm}$ from these samples we produced 50 homogeneous composite soil samples.

\section{Soil analysis}

The soil samples were air-dried at room temperature and passed through a $2 \mathrm{~mm}$ sieve. The weight of fine fraction $(<2 \mathrm{~mm})$ in each soil sample was determined and kept for laboratory analyses. Soil samples of each depth were mixed before analysis to reduce soil heterogeneity.

$\mathrm{pH}$ was measured using a glass electrode $\mathrm{pH}$ meter (McLean 1982), conductivity with electric conductivity meter, (Rhoades 1982), organic matter by Walkley and Black's method (Nelson Sommers 1982); phosphorus by Olsen method (Olsen and Sommers 1982); Carbonate by dry combustion (Iso 1994, see also Nelson and Sommers 1982) and exchangeable cations (Potassium, Magnesium, Calcium, and Sodium) were analyzed with atomic absorption spectrophotometry using a barium chloride solution (Gillman 1979). On the basis of these measurements, we also calculated the $\mathrm{C} / \mathrm{N}$ ration. Nitrogen content was determined by the Kjeldahl Method (Bremner and Mulvaney 1982).

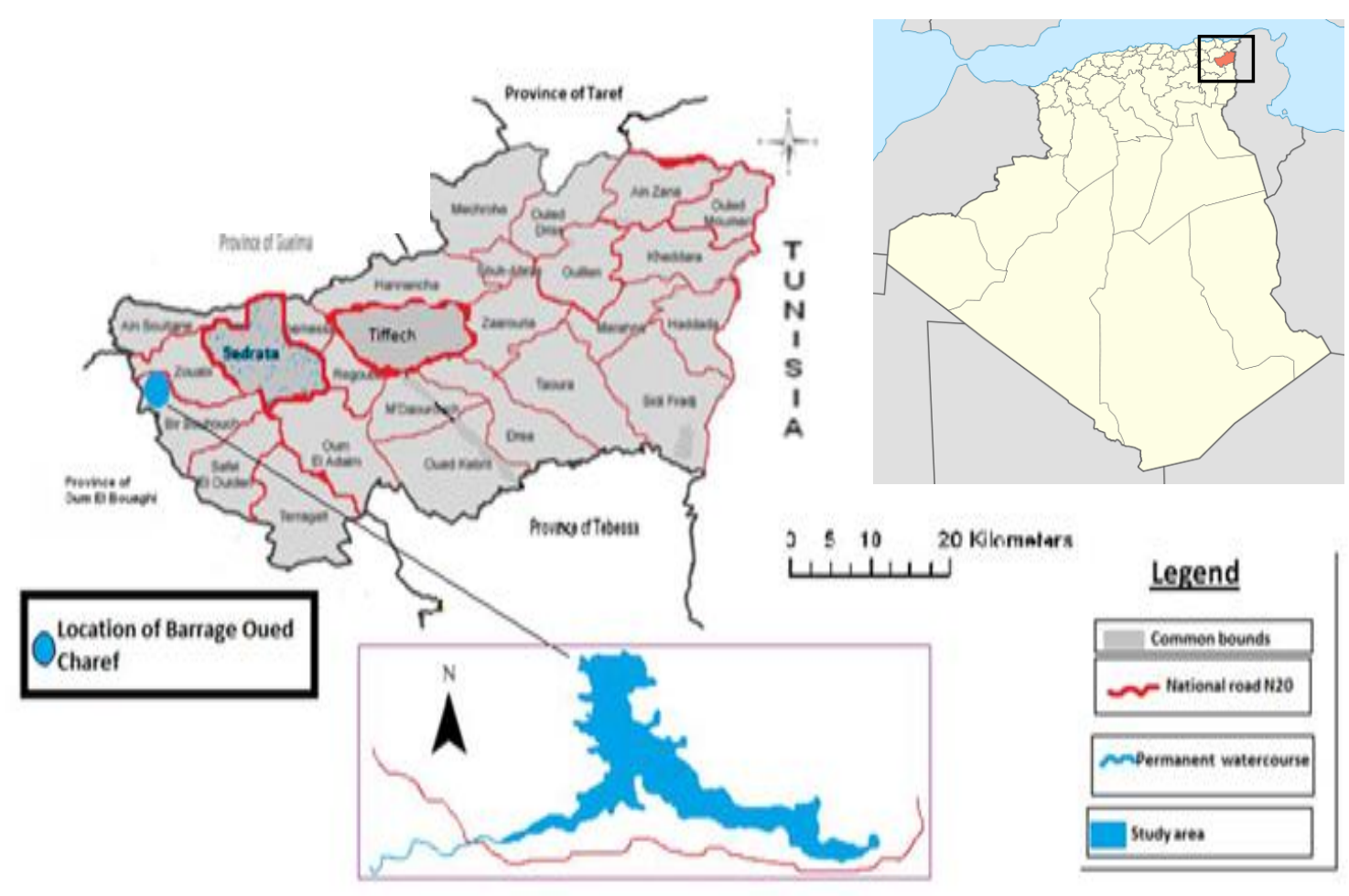

Figure 1. Map showing the location of Oued Charef dam, northeast of Algeria (Established by Boukrouma 2018) 


\section{Data analysis}

The $R$ 4.0.3 software was used for data analysis to calculate arithmetic average, standard deviation, minimum and maximum value for each of the studied features, for each species, and edaphic factors.

To investigate the relationship between the vegetations and environmental factors Ward's Hierarchical Agglomerative clustering techniques (McCune Grace 2002) were used. The importance values index of vegetation was used, as it provides the degree of dominance and abundance of given species in relation to other species in the area. (Kent and Coker 1992; Song et al. 2009). To categorize the vegetation into groups the importance value of species and frequency of understory vegetation was taken.

The classification was performed in the "Facto Miner" package for a program $R$ 4.0.3 (R core Team 2016). After classification of the vegetation, relationships between environmental factors (soil variables) and vegetation were studied using PCA methods. PCA is an ordination technique that constructs the theoretical variable that minimizes the total residual sum of squares after fitting straight lines to species data. PCA does so by choosing the best values for the sites (Jafari et al. 2003). Also, species with high variance, often the abundant ones, therefore dominate the PCA method, whereas species with low variance, often the rare ones, have an only minor influence on the method. These may be reasons to apply standardized
PCA, in which all species receive equal weight (Jafari et al. 2003). Before analysis, the scaling was focused on interspecies correlations, samples were cantered and standardized, but the data were not transformed. The selection of environmental variables was automatic.

\section{RESULTS AND DISCUSSION}

\section{Cluster hierarchical classification of terrestrial species}

The dendrogram was prepared using Ward's Clustering Method, (Figure 2) clearly separate out the six major groups of vegetation and on the basis of these groups, environmental variables are also divided into six groups (Table 1) along with the environmental features of each (Table 2).

Group (1): This group consists of 34 stands (Figure 2). In this group, the dominant species was Daisies chrysanthemum (Table 1). The edaphic feature showed mean value of Sand (FSA) $0.66 \pm 0.01$, Silt (FSI) $57.17 \pm 0.52$, clay $0.85 \pm 0.01$, C/N $14.44 \pm 0.01$, salinity (mg/l) $38.8 \pm 0.42$ and conductivity (us/cm) $82.6 \pm 0.53$. The soil of this group was alkaline having the man value of $\mathrm{pH}$ $7.49 \pm 0.31$. The soil nutrients this group showed the value of nitrates $\left(\mathrm{NO}_{3}\right) 560 \pm 0.03$, nitrites $\left(\mathrm{NO}_{2}\right) 1.8 \pm 0.04$, TN (nitrogen) $300 \pm 0.42$, and phosphorus $14.44 \pm 0.02(\mathrm{mg} / \mathrm{kg})$ respectively (Table 2 ).

\section{Hierarchical Clustering}
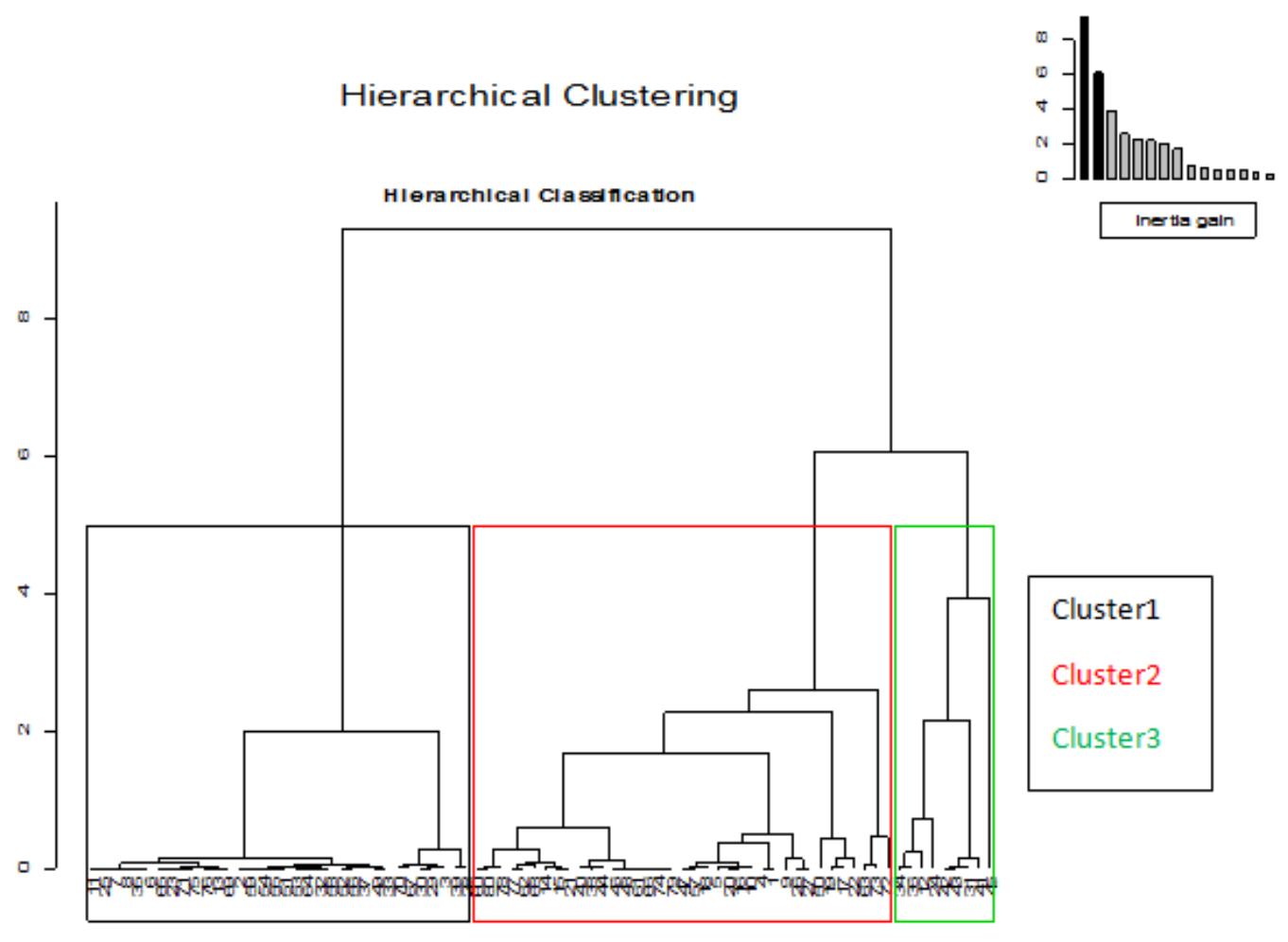

Cluster1

Cluster2

Cluster3

Figure 2. Dendrogram obtained from Ward's Cluster Analysis, using importance value of terrestrial species, showing three distinct groups, Oued Charef dam, northeasten of Algeria 
Group (2): This is the largest group compared to the other cluster groups predominantly by Cynodon dactylon $L$ with $100 \%$ average frequency. (Table 1). The Edaphic feature of this group showed mean value of Sand (FSA) $3.24 \pm 0.01$, Silt (FSI) $69.82 \pm 0.52$, clay $2.69 \pm 0.01$, C/N $4.65 \pm 0.01$, salinity $(\mathrm{mg} / \mathrm{l}) \quad 65.4 \pm 0.42$ and conductivity (us $/ \mathrm{cm}) 81.1 \pm 0.53$. The soil of this group was alkaline having the man value of $\mathrm{pH} 9.04 \pm 0.53$. While in case of the soil nutrients this group showed the value of nitrates $\left(\mathrm{NO}_{3}\right) 270 \pm 0.03$, nitrites $\left(\mathrm{NO}_{2}\right) 6.9 \pm 0.04$, TN (nitrogen) $166 \pm 0.01$, and phosphorus 15.69 $\pm 0.02 \quad(\mathrm{mg} / \mathrm{kg})$ respectively (Table 2$)$.

Group (3): The dominant species in this group is Fumana thymifolia with average frequency of $95 \%$. The Edaphic feature of this group showed mean value of Sand (FSA) 4.59 \pm 0.01 , Silt (FSI) 78.22 \pm 0.52 , clay $1.37 \pm 0.01$, C/N 6.9 \pm 0.01 , salinity (mg/l) $85.3 \pm 0.42$ and conductivity (us/cm) $138.7 \pm 0.53$. The soil of this group was neutral having the man value of $\mathrm{pH} 7.49 \pm 0.53$. While in case of the soil nutrients this group showed the value of nitrates $\left(\mathrm{NO}_{3}\right) 390 \pm 0.03$, nitrites $\left(\mathrm{NO}_{2}\right) 4.4 \pm 0.04$, TN (nitrogen) $133 \pm 0.01$, and phosphorus 26.48 $\pm 0.02 \quad(\mathrm{mg} / \mathrm{kg})$ respectively (Table 2 ).

To determine most effective variables on the separation of vegetation types, PCA was performed on 11 factors in 50 sample plots (Figure 3). The first ordination axis (PC1, $42.1 \%)$ showed a positive correlation with nitrates $\left(\mathrm{NO}_{3}\right)$ phosphorus $\left(\mathrm{PO}_{4}\right), \mathrm{FSA}, \mathrm{FSI}, \mathrm{TN}$, clay, and a negative correlation with $\mathrm{pH}$, conductivity (EC), salinity, $\mathrm{C} / \mathrm{N}$. Defined by the appearance of species: A.mil, A.mre, A.syl, A.mic, B.spi, C.tet, C.cor, CA. vul, C.sol, C.und, C.ari, F.com, G.pus, M.par, M.vul, O.mac, P.arg, P.arg, P.aus, P.cor, R.alb, R.bul, S.hys, S.acr, S.cae, S.ale, S.med, T.nit, U.mar, S.pass, Ci.vul, S.pass, V.tha (Figure 3). In addition, the second component (PC2, 28.5\%) is characterized by a positive correlation with conductivity (EC), salinity, nitrates $\left(\mathrm{NO}_{3}\right)$, nitrites $\left(\mathrm{NO}_{2}\right), \mathrm{TN}$ and negative with $\mathrm{pH}$, $\mathrm{C} / \mathrm{N}, \mathrm{CS}, \mathrm{FSA}$ favoring the appearance of species; A.her, S.leu, E.vul, G.aly, H.spi, A.ber, E.sph, J.sco, C.arv, J.occ, T.gal, E.inc, H.rad, L.ang, D.chy, F.thy (Figure 3).

Table 1. Average frequency of understory terrestrial species in the three groups derived from Ward's cluster analysis of the terrestrial vegetation data, Oued Charef dam, North East of Algeria

\begin{tabular}{llccc}
\hline Species & Code & $\begin{array}{c}\text { Group } \\
\mathbf{1}\end{array}$ & $\begin{array}{c}\text { Group } \\
\mathbf{2}\end{array}$ & $\begin{array}{c}\text { Group } \\
\mathbf{3}\end{array}$ \\
\hline Achillea maritima & A.mar & 60 & 55 & 52 \\
Achillea millefolium & A.mil & 14 & 14 & 0 \\
Agrito berberis trifoliolata & A.ber & 20 & 11 & 60 \\
Ammophila arenaria & A.are & 50 & 50 & 50 \\
Ampelodesma mauritanica & A.mre & 60 & 50 & 18 \\
Anthriscus sylvestris & A.syl & 10 & 9 & 0 \\
Artemisia herba-alba & A.her & 4 & 2 & 8 \\
Asphodelus microcarpus & A.mic & 12 & 2 & 0 \\
Astragalus monspessulanus & A.mon & 68 & 66 & 30 \\
Atriplex halimus & A.hal & 60 & 60 & 20 \\
Belechnum spicant & B.spi & 4 & 0 & 0 \\
Calendula arvensis & C.arv & 43 & 40 & 90 \\
Californica tetragoniatetra & C.tet & 20 & 10 & 10 \\
Canadian horseweed & C.hor & 60 & 56 & 0 \\
\hline
\end{tabular}

\begin{tabular}{|c|c|c|c|c|}
\hline Capsella bursa-pastoris & C.bur & 60 & 45 & 8 \\
\hline Carlina corymbosa & C.cor & 77 & 70 & 0 \\
\hline Carlina vulgaris & C.vul & 70 & 68 & 40 \\
\hline Centaurea solstitialis & C.sol & 79 & 71 & 4 \\
\hline Cirsium undulatum & C.und & 70 & 66 & 33 \\
\hline Cirsium vulgare & C.vul & 70 & 68 & 10 \\
\hline Coronilla varia & C.var & 58 & 47 & 2 \\
\hline Crepis bursifolia & C.bur & 66 & 68 & 43 \\
\hline Cupressus arizonica & C.ari & 15 & 12 & 0 \\
\hline Daisies chrysanthemum & D.chy & 100 & 95 & 82 \\
\hline Daucus carota & D.car & 1 & 1 & 0 \\
\hline Diplotaxis erucoides & D.eru & 80 & 72 & 20 \\
\hline Diplotaxis tenuifolia & D.ten & 80 & 72 & 20 \\
\hline Echinops sphaerocephalus & E.sph & 10 & 10 & 92 \\
\hline Echium asperriumum & E.asp & 0 & 0 & 45 \\
\hline Echium vulgare & E.vul & 10 & 0 & 45 \\
\hline Erucastrum incanum & E.inc & 68 & 58 & 23 \\
\hline Eryngium bourgatii & E.bou & 22 & 12 & 0 \\
\hline Eryngium campestre & E.cam & 30 & 30 & 0 \\
\hline Erysium scoparium & E.sco & 60 & 60 & 80 \\
\hline Ferula communis & F.com & 10 & 8 & 0 \\
\hline Fumana thymifolia & F.thy & 70 & 66 & 95 \\
\hline Geranium pusillum & G.pus & 22 & 25 & 5 \\
\hline Glaucium flavum & G.fla & 44 & 36 & 3 \\
\hline Globularia alypum & G.aly & 0 & 0 & 80 \\
\hline Hedysarum spinosissimum & H.spi & 30 & 25 & 0 \\
\hline Hypochaeris radicata & H.rad & 90 & 92 & 0 \\
\hline Juniperus occidentalis & J.occ & 16 & 16 & 8 \\
\hline Juniperus scopulorum & J.sco & 13 & 11 & 8 \\
\hline Carthamus lanatus & C.lan & 40 & 33 & 6 \\
\hline Cynodon dactylon & C.dac & 95 & 100 & 93 \\
\hline Lagus ovatus & L.ova & 80 & 50 & 60 \\
\hline Eryngium campestre & E.cam & 30 & 20 & 25 \\
\hline Lavandula angustifolia & L.ang & 22 & 20 & 0 \\
\hline Malva parviflora & M.par & 60 & 62 & 0 \\
\hline Marrubium vulgare & M.vul & 20 & 12 & 28 \\
\hline Matthiola incana & M.inc & 19 & 20 & 2 \\
\hline Onopordum macracanthum & O.mac & 30 & 22 & 0 \\
\hline Papaver rhoeas & P.rho & 12 & 10 & 0 \\
\hline paronychia argentea & P.arg & 20 & 18 & 0 \\
\hline Paronychia argentea & P.arg & 20 & 18 & 0 \\
\hline Phragmite australis & P.aus & 32 & 28 & 0 \\
\hline Plantago coronopus & P.cor & 58 & 50 & 2 \\
\hline Raphanus raphanistrum & R.rap & 12 & 20 & 0 \\
\hline Reseda alba & R.alb & 18 & 16 & 0 \\
\hline Romulea bulbocodium & R.bul & 28 & 5 & 0 \\
\hline scilla peruviana & S.per & 25 & 23 & 18 \\
\hline Scolymus hyspanicus & S.hys & 55 & 40 & 2 \\
\hline Scornozera humilis & S.hum & 60 & 40 & 0 \\
\hline Sedum acre & S.acr & 18 & 12 & 0 \\
\hline Sedum caeruleum & S.cae & 10 & 9 & 0 \\
\hline Sedum sediforme & S.sed & 25 & 41 & 45 \\
\hline Senecio leucanthemifolius & S.leu & 0 & 0 & 40 \\
\hline Sonchus asper & S.asp & 50 & 52 & 20 \\
\hline Sonchus oleraceus & S.ale & 22 & 16 & 12 \\
\hline Fallugia paradoxa & F.par & 23 & 25 & 26 \\
\hline Stellaria media & S.med & 18 & 12 & 0 \\
\hline Stoebe passerinoides & S.pass & 28 & 20 & 0 \\
\hline Tamarix gallica & T.gal & 27 & 28 & 0 \\
\hline Thunberg meadowsweet & T.mea & 25 & 24 & 63 \\
\hline Thymelea nitida & T.nit & 19 & 18 & 4 \\
\hline Thymus algeriensis & T.alg & 8 & 10 & 8 \\
\hline Urginea maritima & U.mar & 45 & 48 & 0 \\
\hline Verbascum thapsus & V.tha & 30 & 30 & 0 \\
\hline Eriogonum latifolium & E.lat & 25 & 63 & 47 \\
\hline Xanthium strumarium & X.str & 22 & 11 & 0 \\
\hline
\end{tabular}


Table 2. Mean values and standard error $( \pm$ SE) values of the soil variables in the vegetation groups (1-3) obtained by TWINSPAN classification in Oued Charef dam, North East of Algeria

\begin{tabular}{|c|c|c|c|c|}
\hline \multirow{2}{*}{ Soil variables } & \multirow{2}{*}{ Mean } & \multicolumn{3}{|c|}{ Vegetation groups } \\
\hline & & 1 & 2 & 3 \\
\hline Sand (FSA) \% & $2.83 \pm 0.01$ & $0.66 \pm 0.01$ & $3.24 \pm 0.01$ & $4.59 \pm 0.01$ \\
\hline Silt (FSI) \% & $74.40 \pm 0.52$ & $75.17 \pm 0.52$ & $69.82 \pm 0.52$ & $78.22 \pm 0.52$ \\
\hline Clay \% & $1.63 \pm 0.01$ & $0.85 \pm 0.01$ & $2.69 \pm 0.01$ & $1.37 \pm 0.01$ \\
\hline Salinity $\mathrm{mg} / \mathrm{l}$ & $63.16 \pm 0.42$ & $38.8 \pm 0.42$ & $65.4 \pm 0.42$ & $85.3 \pm 0.42$ \\
\hline Conductivity (EC) us/cm & $100.8 \pm 0.53$ & $82.6 \pm 0.53$ & $81.1 \pm 0.53$ & $138.7 \pm 0.53$ \\
\hline $\mathrm{pH}$ & $8,66 \pm 0.53$ & $7,49 \pm 0.31$ & $9,04 \pm 0.31$ & $7,49 \pm 0.31$ \\
\hline Nitrates $\left(\mathrm{NO}_{3}\right) \mathrm{mg} / \mathrm{kg}$ & $390 \pm 0.03$ & $560 \pm 0.03$ & $270 \pm 0.03$ & $390 \pm 0.03$ \\
\hline Nitrites $\left(\mathrm{NO}_{2}\right) \mathrm{mg} / \mathrm{kg}$ & $4.36 \pm 0.04$ & $1.8 \pm 0.04$ & $6.9 \pm 0.04$ & $4.4 \pm 0.04$ \\
\hline $\mathrm{TN}$ (nitrogen) $\mathrm{mg} / \mathrm{kg}$ & $199 \pm 0.42$ & $300 \pm 0.42$ & $166 \pm 0.42$ & $133 \pm 0.42$ \\
\hline Phosphorus mg/kg & $18.87 \pm 0.02$ & $14.44 \pm 0.02$ & $15.69 \pm 0.02$ & $26.48 \pm 0.02$ \\
\hline $\mathrm{C} / \mathrm{N} \%$ & $4.22 \pm 0.01$ & $1.12 \pm 0.01$ & $4.65 \pm 0.01$ & $6.9 \pm 0.01$ \\
\hline
\end{tabular}

Note: SE: Standard error, EC: Electrical conductivity

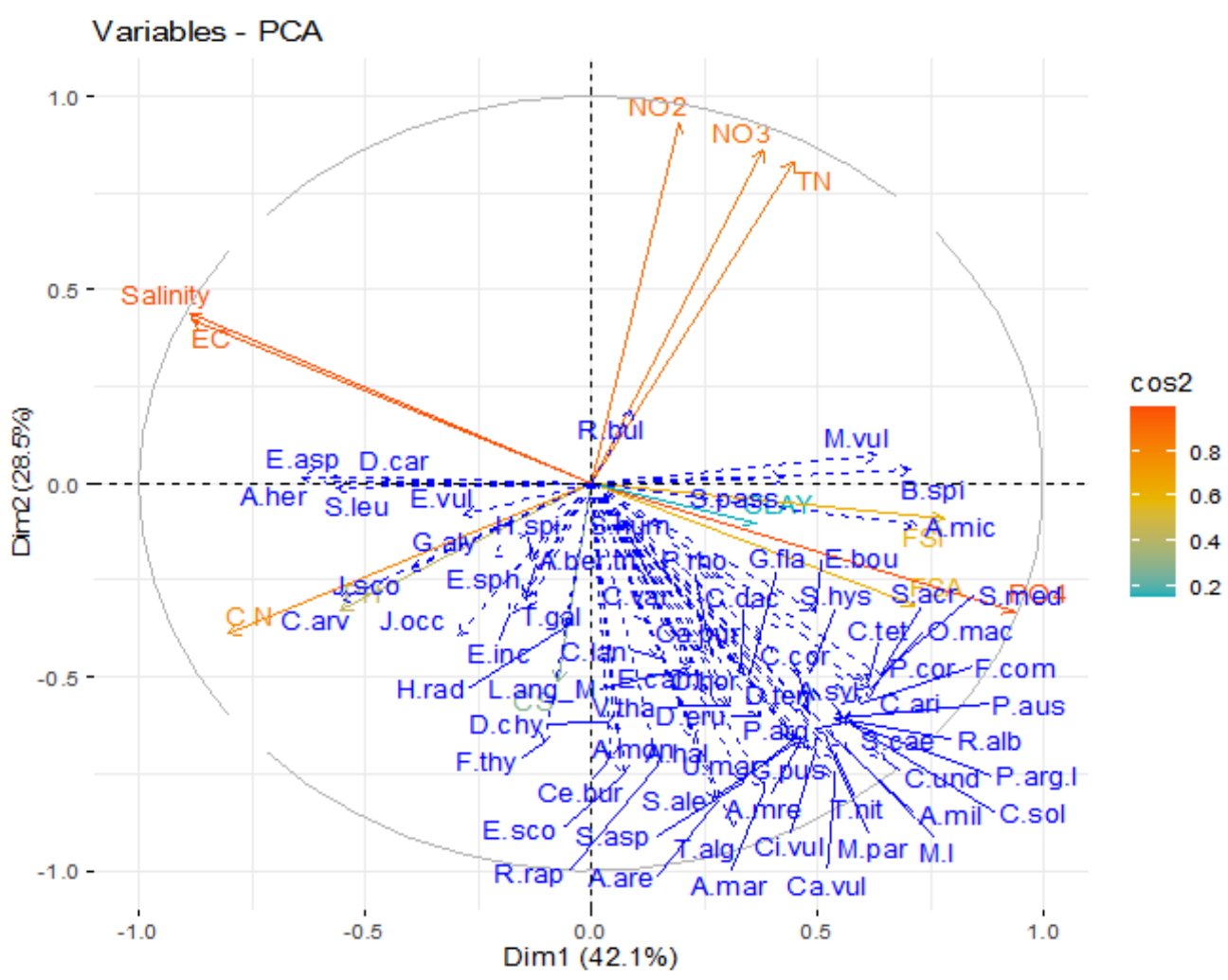

Figure 3. A plot of terrestrial species against their values for axes 1 and 2, Oued Charef dam, northeastern of Algeria

\section{Discussion}

Environmental factors indeed hierarchically play a key role in distribution and composition of association. Lovtt et al. (2001) and Gajoti et al. (2010) described that the environmental variables contribute very important role in classification of species groups. By Ward's cluster analysis, species groups were recognized as vegetation data domination with various plant species. In the present study, the application of PCA ordination indicated that the most effective soil variables correlated with the presence and distribution of the species elements in the vegetation of
Oued Charef dam are: conductivity (EC), FSA, FSI, clay, salinity, phosphorus $\left(\mathrm{PO}_{4}\right), \mathrm{TN}$ (nitrogen), nitrates $\left(\mathrm{NO}_{3}\right)$ and nitrites $\left(\mathrm{NO}_{2}\right)$. Similar results were found in lowlands, temperate forests, arid grasslands, beech forests, and natural forests (Peres-Neto et al. 2006, Dwirek et al. 2006). Plant communities are affected by many factors as farm management practices (Andersson and Milberg 1998), crop species (Andreasen and Skovgaard 2009), season (ElDemerdash et al. 1997), and soil characteristics (Pinke et al. 2010). 
One of the effective variables in the separation of species in the study is conductivity. Similarly, Monier et al. (2006), who categorized 25 plant populations using soil properties, found that conductivity was one of the most important factors. Shaltout et al. (2002) concluded that conductivity was a key factor in species community separation. Conductivity contains rich information about physical properties and soil quality, which is crucial for plant growth (Jager et al. 2015).

Adel et al. (2014) identified soil texture (clay, FSA, FSI) as the main factors affecting the distribution of plant communities in northern Iran. These results agree with our findings. Also, Badano (2005) reported role of clay, as a key factor in the distribution of plant species in Mediterranean matorral of central Chile. Other researchers such as Zarei (2010) and Naseri (2009) proved that soil texture (proportions of clay, silt (FSI) and sand (FSA)) are one of the most important factors in determining plant distribution. Ismaelzade et al. (2011) associated the amount of sand with developing different types of plant forests. The proportions of clay and sand in soil are drivers of vegetation distribution, because sandy soils have lower water retention capacity and cation exchange capability (Larcher 1995). Some species can become more competitively aggressive with more nutrients adsorbed in high organic matter and clay soils.

Salinity was one of the most important soil factors determining the occurrence of terrestrial species group in this study. These results agree with the findings of Shaltout et al. (2002).

Phosphorus and nitrogen (TN) were one of the important soil factors in the separation of the ecological groups in Oued Charef dam. These findings agree with Biggelow and Canham (2002) who documented positive association of Phosphorus and nitrogen content with plant species in northeastern America. Amorin \& Batalha (2007) reported that phosphorus was the main factor that defined plant communities in Brazil, and nutrients, in general, played a major role in the classification of ecological groups. Nitrogen is a key nutrient in many biological processes and itis the main factor in plant growth. It also has a major influence on soil fauna and flora that can either make nutrients more available to plants or bind them in biological processes and growth causing short-term deficiencies in plants (Abella and Covington 2006; Jiang et al. 2012). Phosphorus is a key element in cellular energy transfer and a structural element in nucleic acids. Nitrogen and Phosphorus are also the primary nutrients that restrict plant growth in many natural environments (Jiang et al. 2012). High soil nitrogen content might promote resprouting vigor in many species (Di Tommaso and Aarsen 1989; Wilson and Tilman 1993), predicting that more re-sprouters will be found in soil patches with high nitrogen content. The presence of nitrogen changes the relationship between plants and soil resources (Hector and Loreau 2005).

Our results showed that the presence of species plants is related to nitrates and nitrites. These results are similar to the report by Su et al. (2002) and Zhenghu et al. (2004) in the Tengger Desert of China. Nitrates and nitrites are the key nutrients in many biological processes and there is the main factor in plant growth. They also have a major influence on soil fauna and flora that can either make nutrients more available to plants or bind them in biological processes and growth causing short-term deficiencies in plants. (Fu et al. 2004).

Our results showed that $\mathrm{pH}$ factor does not play an important role in the vegetation community succession process. Jobbagy and Jackson (2003) have reported that soil $\mathrm{pH}$ is an important determinant of the productive capability of plant species. Kashina et al. (2003), Gough et al. (2000), and Brofske et al. (2001) demonstrated the important role of $\mathrm{pH}$ in the separation of plant groups. This finding degree with our results.

This difference could be explained by a specific limitation threshold for some soil resources. So, wetland management must work with vegetation communities by taking into account all of the interrelated biotic and abiotic influences. Understanding the relationships between environmental variables and vegetation distribution can improve the management, reclamation, and development of wetland ecosystems.

In conclusion, the ability to identify ecological species groups and understand the environmental relationships that underlie their occurrence in this wetland can be used to evaluate site conditions, assess the quality of current vegetation, identify priority sites for restoration and determine appropriate species for specific sites. This study showed relationship between variation in soil characteristics and plant populations in Oued Charef dam. However, due to its large surface and small number of plots, this study has not completely described the species plant of the wetland. Further studies with more sample plots located by considering the surface of habitat will give a more comprehensive description of the relationship between soil characteristics and plant populations in Oued Charef wetland.

More studies can be conducted to add ecological understandings and help biodiversity conservation. For example, other environmental factors including atmosphere, water level, climate, rainfall, or others should be studied to better understand the effect's environmental factors on plant biodiversity. Another topic is the study of relationships of plant biodiversity with productivity and soil fertility in different ecosystems. Currently, the study area as a strict nature reserve has been drastically changed by human induce and other natural disturbances, and therefore should be restored.

\section{REFERENCES}

Abella SR, Covington WW. 2006. Vegetation environment relationships and eco-logical species groups of an Arizona Pinus ponderosa landscape. Plant Ecol 185 (2): 225-268.

Adel MN, Pourbabaei H, Dey DN. 2014. Ecological species group. Environmental factors relationships in unharvested beech forests in the north of Iran. Ecol Eng 69: 1-7.

Amorin PK, Batalha MA. 2007. Soil vegetation relationship in hyperseasonal Cerrado and wet grassland in Emas National Park (Central Brazil). Acta Oecologica 32: 319-327. 
Andersson TN, Milberg P.1998. Weed flora and the relative importance of site, crop, crop rotation, and nitrogen. Weed Sci 46: 30-38.

Andreasen C, Skovgaard IM. 2009. Crop and soil factors of importance for the distribution of plant species on arable fields in Denmark. Agric Ecosyst Environ 133: 61-67.

Badano E I. 2005. Slope aspect influences association pattern in the Mediterranean natural of central Chile. J Arid Environ 62: 93-108

Biggelow SW, Canham CD. 2002. Community organization of tree species along soil gradients in a north-eastern USA forest. J Ecol 90: 188-200.

Boukrouma N.2017. Breeding biology of the Mallard duck (Anas platyrhynchos) in Barrage Oued Charef (Souk Ahras, Northeastern Algeria). Indian J Ecol 44 (2): 394-398.

Braun Blanquet J. 1964. Pflanzensoziologie. Grundziige der vegetations Kunde. Springer, Wien.

Bremner JM, Mulvaney CS. 1982. Nitrogen-total. In: Page AL, Miller RH, Keeney DR (eds.). Methods of Soil Analysis: Part 2 Chemical And Microbiological Properties, 2nd ed. American Society of Agronomy, Madison, WI.

Brofske KD, Chen J, Crow TR. 2001. Understory vegetation and site factors: implications for a managed Wisconsin landscape. For Ecol Manag 146: 75-87.

Dekeyser E S, Kirby D R, Ell M J. 2003. An index of plant community integrity: development of the methodology for assessing Prairie Wetland Plant Communities. Ecol Indic 3 (2): 119-133.

Di-Tommaso A, Aarsen LW. 1989. Resource manipulations in natural vegetation: a review. Plant Ecol 84: 9-29.

Dwirek A, Kauffman J B, Baham J E. 2006. Plant species distribution in relation to water-table depth and soil redox potential in Montane Riparian Meadows. Wetlands 26: 131-146.

Dybzinski R, Fargione J E, Zak D R, Fornara D, Tilman D. 2008. Soil fertility increases with plant species diversity in a long-term biodiversity experiment. Oecologia 158 (1): 85-93.

El-Demerdash M A, Hosni HA, El-Ashri N.1997. Distribution of the Weed Communities in the North East Nile Delta, Egypt. Feddes Repertorium 108: 219-232.

Enright NJ, Miller BP, Akhter R. 2005. Desert vegetation and vegetationenvironment relationships in Kirthar National Park, Sindh, Pakistan. J Arid Environ 61: 397-418

Fu BJ, Liu SL, Ma K M., Zhu YG. 2004. Relationship between soil characteristics, topography and plant diversity in a heterogeneous deciduous broad-leaved forest near Beijing, China. Plant Soil 261: 4754

Gillman GP. 1979. A proposed method for the measurement of exchange properties of highly weathered soils. Australian J Soil Res 17: 129 139.

Givnish T J.1999. On the causes of gradients in tropical tree diversity. J Ecol 87 (2): 193-210.

Gojoti TE, Haciyev V, Javanshir A, Nosrat H, Haghighi AR, Eimanifar A Stewart Jr N. 2010. Vegetation analysis of Sutan-Chay Basin in Arasbaran. Am J Agric Boil Sci 5: 357-362.

Grolle R, Long DG.2000. An annotated checklist of the Hepaticae and Anthoceros of Europe and Macaronesia. J Bryol 22: 103-140.

Grongroft A, Petersen A, Miehlich G. 2003. Edaphical diversity and biodiversity in mutual dependency project, ID: 01 LC 0024, BIOTA AFRICA So2.

Hebb AJ, Mortsch LD, Deadman PJ, Cabrera AR. 2013. Modeling wetland vegetation community response to water-level change at Long Point, Ontario. J Great Lakes Res 39 (2): 191-200.

Hector A, Beale A, Minns A, Otway SJ, Lawton JH. 2000. Consequences of loss of plant diversity for litter decomposition: effects through litter quality and microenvironment. Oikos 90: 357-371.

Ismaelzade O, Hoeini SA, Tabari M, Asadi H. 2011. Classification system analysis in classification of forest plant communities (case study: Darkola's beech forest). Iranian J Plant Biol 3 (7): 11-28.

Iso.1994. Soil quality. Determination of organic and total carbon after dry combustion. International Organization For Standardization, Geneve.

Jafari M, Chahouki M A Z, Tavili A. 2003. Effective environmenta factors in the distribution of vegetation types in postcoup rangelands of Yazd province (Iran). J Arid Environ 56 (4): 627-641.

Jager NRD, Rohweder J J, Yao Y, Hoy E. 2015. The Upper Mississipp River Floodscape: $\mathrm{S}$

patial patterns of flood inundation and associated plant community distributions. Appl Veget Sci 19: 164-172.

Janssens F, Peeters A, Tallowin J R B.1998. Relationship between soil chemical factors and grassland diversity. Plant Soil 202 (1): 69-78.
Jiang C, Yu G, Li Y, Cao G, Yang Z, Sheng W, Yu W. 2012. Nutrient resorption of coexistence species in alpine meadow of the QinghaiTibetan Plateau explains plant adaptation to nutrient-poor environment. Ecol Eng 44: 1-9.

Jobbagy EG, Jackson RB.2003. Patterns and mechanisms of soil acidification in the conversion of grasslands to forests. Biogeochemistry 64: 205-229.

Kang S, Kang H, Ko D 2002. Nitrogen removal from a riverine wetland: a field survey and simulation study of Phragmites japonica. Ecol Eng 18: 467-475.

Kashina DM, Barnes BV, Walker W.S. 2003. Ecological species group of landform level ecosystems dominated by jack pine in northern Lower Michigan, USA. Plant Ecol 166: 75-91.

Kent, M, Coker P. 1992. Vegetation Description and Analysis: A Practical Approach. Belhaven Press, London.

Larcher W. 1995. Physiological plant ecology. New York, Springer.

Li W, Li J, Cui XS, Zhao MY, Zhang YF, Wang W. 2010.Spatial distribution of vegetation and soil interpretation in the process of wetland restoration with the type of sand-mining land. Ecol Environ Sci 19: 2325-2331.

Lovett JC, Clarke GP, Moore R, Morrey GH. 2001. Elevation distribution of restricted rang forest tree taxa in eastern Tanzania. Biodiv Conserv 10: 541-550.

Martincic A, Wraber T, Jogan N, Ravnik V, Podobnik, Turk B, Vres B.1999. Mala flora slovenije, kljuc za dolocevanje praprotnic in Smenk Tehniska zalozba slovenije ljinbljna, Slovene edition, Slovene, p, 521 .

Mccune B, Grace JB. 2002. Analysis of Ecological Communities, MjM Software Design, Gleneden Beach, Oregon, USA.

Mclean EO.1982. Soil pH and lime requirement. In: Page AL, Miller RH, Keeney DR (eds.). Methods of Soil Analysis: Part 2 Chemical And Microbiological Properties, 2nd ed. American Society of Agronomy, Madison, WI.

Monier M, Ghani AE, Marei AH. 2006. Vegetation associates of the endangered Randonia africana and its soil characteristics in an arid desert ecosystem of western Egypt. Acta Botanica Croatica 65 (1): 83-99.

Muller D D, Ellenberg H.1974. Aims and Methods of Vegetation Ecology, John Wiley and Sons, New York.

Naseri H. 2009. Study of relationship between physical and chemical soil characteristics with plant communities of playa (case study: southern Kashan playa). J Range management 4: 652-667.

Nelson D W, Sommers L E.1982. Total carbon, organic carbon and organic matter. In: Page AL, Miller RH, Keeney DR (eds.). Methods of Soil Analysis: Part 2 Chemical And Microbiological Properties, 2nd ed. American Society of Agronomy, Madison, WI.

O'Connell J L, Johnson L A, Smith L M, Mcmurry S T, Haukos D A. 2012. Influence of land-use and conservation programs on wetland plant communities of the semiarid United States Great Plains. Biol Conserv 146 (1): 108-115.

Oberdorfer E. 1983. Pflanzensoziologische Exkursions Flora, Ulner, Stuttgart.

Oberdorfer E.1992. Suddeutsche of lanzeng esellschften. Gustav Fischer, Jena Stuttgart and New York.

Olesen B, Madsen TV.2000. Growth and physiological acclimation to temperature and inorganic carbon availability by two submerged aquatic macrophyte species, Callitriche ophiocarpine Elodea canadensis. Funct Ecol 14: 252-260.

Peres-Neto P R, Legendre P, Dray S, Borcard, D. 2006. Variation partitioning of species data matrices: estimation and comparison of fractions. Ecology 87: 2614-2625.

Pinke G, Pál R, Botta-Dukát Z. 2010. Effects of environmental factors on weed species composition of cereal and stubble fields in western Hungary. Central Eur J Biol 5 (2): 283-292.

R Development Core Team. 2016. R. A language and environment for statistical computing R Foundation for Statistical Computing. Vienna, Austria.

Rhoades JD. 1982. Soluble salts. In: Page AL, Miller RH, Keeney DR (eds.). Methods of Soil Analysis: Part 2 Chemical And Microbiological Properties, 2nd ed. American Society of Agronomy, Madison, WI.

Shaltout KH, Sheded MG, El-Kady HF, Al Sodany Y. 2002. Phytosociology and size structure of Nitrararia restusa along the Egyptian Red Sea coast. J Arid Environ 53: 331-345. 
Skeffington M S, Moran J, Connor ÁO, Regan E, Coxon CE, Scott NE. 2006. Turloughs Ireland's unique wetland habitat. Biol Conserv 133 (3): $265-290$

Song C, Huan LG, Sheng LQ.2009. Spatial and environmental effects on plant communities in the Yellow River Delta, Eastern China. J For Res 20 (2): 117-122.

Su YZ, Zhao HL, Zhang TH. 2002. Influencing mechanism of several shrubs and subshrubs on soil fertility in Horgin sandy land. Chines J Appl Ecol 13 (7): 802-806.

Wang Y, Huang J C, Yan R H, Gao J. 2016. Nutrient removal efficiency of lake wetlands: a case study of Sanshan Wetland in Lake Taihu, Eastern China. J Lake Sci 28: 124-131.

Wetser K, Liu J, Buisman C, Strik D. 2015. Plant microbial fuel cell applied in wetlands: spatial, temporal and potential electricity generation of Spartina anglica, salt marshes and Phragmites australis, peat soils. Biomass Bioenerg 83: 543- 550.
Williams L D, Ahn C. 2015. Plant community development as affected by initial planting richness in created mesocosm wetlands. Ecol Eng 75: $33-40$.

Wilson SD, Tilman D. 1993. Plant competition and resource availability in response to disturbance and fertilization. Ecology 74: 599-611.

Zarei A. 2010. Determined of properties of soil effect on distribution of vegetation in mountain ranges of salt Qom province. J Range Manag 3: 412-421.

Zheng JG, Chen YW, Wu GX. 2013. Association of Vegetation Patterns and Environmental Factors on the Arid Western Slopes of the Helan Mountains, China. Mountain Res Dev 33: 323-331.

Zhenghu D, Hanglang X, Xinrong L, Zhibao D, Gang W. 2004. Evolution of soil properties on stabilized sands in the Tengger Desert, China. Geomorphology 59: 237-246. 